\title{
Pesantren Agility in Community Economic Development
}

\author{
R. Lukman Fauroni' ${ }^{1 *}$ Mujahid Quraisy ${ }^{2}$ \\ ${ }^{1}$ IAIN Surakarta, Indonesia, ${ }^{2}$ STEI Yogyakarta, Indonesia
}

Submitted: 4 September, 2019; Accepted: 16 March, 2020; Published: 20 March, 2020

\begin{abstract}
This study aims to elaborate on the pesantren agility viewed from the aspects of sources and its implementation in the community economic development. The research uses the case study method. The research finds that pesantren agility is sourced from the traditional intellectual pesantren, the implemented integration of Islamic teaching and values in social-economic fields. Pesantren agility is the epicenter for the strength of socioeconomic functions, particularly the development of the community's economy through the transformation and expansion of pesantren institutional services. The pesantren agility has been applied in community economic development according to the economic needs.
\end{abstract}

Keywords: pesantren agility, intellectual capital, community economic development

\begin{abstract}
Abstrak
Kajian ini bertujuan mengelaborasi agilitas pesantren dari aspek sumber dan implementasinya dalam pengembangan ekonomi komunitas. Metode penelitian menggunakan studi kasus. Ditemukan agilitas pesantren bersumber dari modal intelektual tradisi pesantren dan implementasi integrasi ajaran agama Islam dalam bidang sosial ekonomi. Agilitas pesantren merupakan episentrum bagi kekuatan fungsi sosial ekonomi khususnya dalam pengembangan ekonomi komunitas melalui transformasi perluasan fungsi kelembagaan pesantren. Agilitas pesantren diaplikasikan dalam pemberdayaan ekonomi komunitas sesuai kebutuhan dasar ekonominya.
\end{abstract}

Kata kunci: agilitas pesantren, modal intelektual, pengembangan ekonomi masyarakat

\footnotetext{
* Corresponding author 


\section{INTRODUCTION}

Agility is an organization's flexibility ability in understanding and dealing with its external environment. Originally, agility is developed in a business organization, but it then becomes a concept of initiation and implementation of organizational structural and cultural transformation. It also means smartness, nimbleness, or flexibility in dealing with external challenges applied to an organization with a synchronous up and bottom strategy (Chrisen, 2007).

Agility is also understood as an integration of the practical knowledge management ability in responding to the external change quickly, efficiently, and accurately, adapting appropriately and proactively, and the need for the business opportunity or customer management without sacrificing cost and process and product qualities (Ganguly, Nilchiani, \& Farr, 2009). Agility ability is needed to respond to unexpected environmental changes proactively. At this point, a commitment is required to conduct strategic transformation continuously and have implication to all organizational levels, from structure, leadership, to dynamic decision making. Agility is crucial to help leaders in dealing with and adapting organizational culture to be more effective and proactive, thereby achieving the ideal culture (Felipe, Roldan \& Leal-Rodriguez, 2017).

Two agility aspects are interdependent nature; strategic and operational. At the strategic level, an outward-orientation approach is required, observing the environment and assessing the effect of economic trends, technology acceleration, competition power, change, and market dynamics. The planning will not be adequate, but with short term strategic decision and commitment. After that, the next step goes to the process and involves the internal operational level with excellent innovation.

Generally, agility is an organization's smartness and skill in managing its resources in dealing with a variety of external challenges. One of them is the challenges coming from intellectual capital. It is directly related to agility. Organizational agility and intellectual capital lead to the productivity of human resources through spiritual leadership. Organizational agility and intellectual capital come up with a company's productivity (Hajevar \& Kharazian, 2016). Organizational agility is significantly influenced by knowledge management. Agility can optimize the function of amalgamation, combining individual and group competencies under the organization. Through a knowledge management strategy, the organization becomes agile and achieves a competitive advantage (Saha, Gregar \& Saha, 2017).

The improvement of an organization's agility ability is needed to respond proactively to the unexpected environmental change. A commitment is required to conduct continuous strategic transformation that implies all organizational levels, from structure, leadership, to the 
dynamic decision made to improve interpersonal skill in implementing the mission of agility. According to Singh, Sharma, Hill, Schnackenberg (2013), uncontemporary organizations significantly need agility. The organization agility can be developed through 3 (three) components of knowledge management, such as real-time ability, transformation capability, and strategic option ( $\mathrm{Su}, 2011)$. Practically, a production company comes from an agility environment. Although it has community funds' support, the company agility can support the sustainability of the community's social-economic environment (Perera, Soosay, \& Sandhu, 2014).

Community Economic Development (CED) is one of the community empowerment patterns which focus on the community. According to Amstrong, Kehrer, Wells, and Wood (2000), CED should have four characteristics: first, having some essential purposes for the better economic life; second, leading to achieve many benefits for members of group or community; third, stabilizing the vision and mission for a long term; and fourth, performing general social welfare in the community. Setyawan (2017) finds that the community's economic development can build solidarity and solidity in developing citizen-based Raman Dam tourism in Metro City. This area is previously unsafe and ignored. Then it changes into a tourist area that supports the development of the economy. Through the ethnographic approach, intellectual people become one of the primary growth- factors.

In rural areas of Girianyar, Bali, non-agricultural economic development movement occurs in industry and household, trading, service, and laborer (Adi, Astawa, Taun, \& Widjaja, 2016). Pabbajah (2017) finds that religiosity-based social-economic community empowerment through the lower-middle community makes an active, creative, and independent community. In line with Pabbajah, Wibowo's (2017) study states that the economic dynamic of the industrial batik community in Karangkajen Yogyakarta is affected significantly by a religious spirit, particularly Muhammadiyah organization, for long periods.

Agility in the optimization and function of an organization and benefit value to the community's economic empowerment becomes an interesting issue to be mainly learned in the social-nuanced organization like Pondok Pesantren (Islamic Boarding School). Several pondok pesantren or simply called as pesantren have passed through its primary function and role as the social-education institution and also has activated the religious community (umat) economy in economic development.Thus, many pesantren not only focus on their alumni's output but also on their outcomes, including precious value to society and the nation's economic growth. Specifically, financial independence pesantren, the outcome added-value lies in the expansion of pesantren's function in activating and empowering the umat economy. As a social-education 
institution with a large number in this archipelago, pesantren has uncountable intellectual and social capital wealth. It is the social capital wealth that makes it survived and dynamically contributed to the Indonesian nation's journey since pre-independence until now.

Pesantren Al-Ittifaq, Bandung; and Pesantren Al-Amin, Prenduan; are the examples of pesantren who succeed in expanding their institutional function into community economic development (CED). The community's economic growth is inseparable from the economic activities that happened in the city, village, or pesantren areas. The community of pesantren AlIttifaq, Bandung, concentrates on the agribusiness-based economic development because of the location of the pesantren is in a mountain area. Similarly, the community of pesantren AlAmin, Prenduan, focuses on the maritime economy because it is located in a coastal area.

Thus, the above findings encourage the significance of this research on the agility of non-profit organizations, such as pesantren. In this study, the researchers will focus mainly on the agility in community economic development of pesantren Al-Amin, Kawalu, Tasikmalaya. The study on the agility of pesantren Al-Amin, Kawalu, Tasikmalaya, is engaging because of its unique history. This pesantren is established from a small community-based embroidery garment business in the neighborhood. Then it grows later after 30 years. This phenomenon becomes the reason for conducting this research.

\section{METHOD}

This research uses qualitative research with an instrumental case study. It is aimed to explore the typical, rare, and strategic characteristics of the phenomenon of organization agility in pesantren Al-Amin, Kawalu, Tasikmalaya, comprehensively. It highlights the economic business development and community economic development (CED) programs (Bogdan \& Biklen, 1992).

Qualitative research emphasizes the study of social-cultural and religious phenomena occurred naturally rather than conditionally. This type of research is appropriate to construct intellectual and social-economic capitals of pesantren as the source of agility and added-value to the community economic empowerment (Creswell, 1998). Then the researchers use a case study to reveal the depth of typical characteristics of social phenomena, including values, norms, mental attitude, culture, and its implementation (Yin, 1984). Therefore, triangulation is used to find data analysis. 


\section{RESULT AND DISCUSSION}

\section{Pesantren As A Solution}

Pesantren Al-Amin was built in consideration of the leaders' vision and mission in Tasikmalaya to establish a pesantren that focus on economic development. This pesantren is created with the spirit of realizing an ideal of Muslim in the earth, by applying the powers of science (ilmiah), spirituality (ruhiyah), and good deed (amaliyah). Pesantren itself is located in Tasikmalaya. Meanwhile, Tasikmalaya Regency has more than 800 pesantren out of 9.167 pesantren in West Java. The garment business surrounds the environment of the pesantren. Thus, a solution is needed to solve the economic problems such as unfair competition, competitive market, lower productivity and business relationship between previously fellow embroidery business and employees who participate in the establishment of pesantren (KH. Wawan Nawawi, personal communication, 2018)

Pesantren Al-Amin has two garment factories. They are CV. Tjiwulan Bordir and PT. Tjiwulan Putra Mandiri. Those factories focus on the export production of embroidery garments to many countries in West Asia, Africa, and Europe. As a consequence of its commercial businesses, this pesantren has many community economic empowerment programs.

Pesantren Al-Amin manages modern and traditional embroidery garments (factories) with 400 employees and tailors in several cities, including East Java. Meanwhile, in the education and social sector, this pesantren manages Integrated Islamic Junior High School, Islamic Senior High School, Islamic education, hajj/pilgrimage guidance, recitation event, etc.

Contrasting to pesantren in general, Al-Amin has its typical characteristics. This pesantren has inseparable history from Tjiwulan embroidery business, which belongs to Haji Zarkasyi, who has a dream of having an Islamic Education Foundation. The embroidery business starts from 1961-1975. In 1987, an embroidery education institution was established. Recitation event developed only in 1998 and continues again in 2000 by the establishment of Pesantren Al-Amin (KH. Wawan Nawawi, personal communications, 2018).

Through embroidery economic business, pesantren Al-Amin can create pesantren's independence to organize educational, social-economic functions, and community economic empowerment. Then, the development of the embroidery garment industry integrates with its pesantren education system. Moreover, social-cultural and spiritual capitals create economic agility of pesantren Al-Amin. The agility performance maintains its competitiveness and productivity, particularly in community economic development. 


\section{Social-Spiritual Foundation, the Root of Pesantren Independency}

The world of pesantren is known inherently from Indonesian Islamic for the traditional nuance, a tradition living, growing, and developing on Islam's ideal (Suyata, 1985). Pesantren has affected thousands santri and surrounding people, creating social-economic and even political movement by assuming the Islamic, Indonesian Identity, and humanity missions (Fauroni, 2014). Historically, pesantren is a result of the parallel development of a pre-Islamic educational institution that has institutionalized for centuries. Pesantren also related to the preIslamic institutions that already exist since the Hindu-Buddha dominating period, so that Islam brings influence on some education institutions at that time (Ziemek, 1986).

Kiai (the leader) voluntarily leads pesantren. First, he usually finds an empty land which is far away from the hometown. Kiai then utilizes forest and preaches there. Second, the bond between teacher and student is similarly close between kiai and santri. The 'fatherliness' bond between an individual and others, appears as the primary bond during the Hindu-Buddha kingdom period or even before. Third, there is a relationship between pesantren and pre-Islam religious institutions (dharma), for example, seeking spiritual deed from one place to another.

The social structure system of pesantren is constructed from intellectual and spiritual capitals. The social-cultural capital of pesantren can be seen from three perspectives: firstly, the educational process as a necessary process in a particular life. It includes individual and group's mental, character, and ability to grow and develop. This perspective actively makes the relationship between idea and behavior that can perceive as intellectual capital.

Secondly, the educational system in pesantren includes history, culture, tradition, and development over time. Pesantren is the result of the process of searching for Islamic knowledge from its source. Thirdly, a social dynamic always needs socio-cultural and spiritual capital. Pesantren is an organization of the social system that relates to several social-cultural equities. However, economics' behavior shall reflect Islamic deeds as a mandate of Haji Zarkasyi, the founder of Tjiwulan embroidery business and pesantren Al-Amin. The existence of social-cultural and spiritual capital is a transaction in social structure and function. It is not only economic capital as theories but also social and cultural capital. Social capital, as a whole aspect, enables everyone to implement its social structure, including pesantren. Social capital is several high values underlying collective action for the mutual objective, including high values and intellectuality of pesantren (KH. Abdul Muhsin, personal communication, 2018).

Social-cultural capital belongs to pesantren's dynamic history. Pesantren begins to reach the educational, social, political, and economical domains. Pesantren and economic program development can be traced from the 1970s when several pesantren leaders initiate to conduct the community empowerment. 
The initiative concern of pesantren's multifunction is confirmed by Steenbrink (1986), Horikoshi (1987), Dhofier (1982), and Ziemek (1986). Pesantren and Kiai have played an essential role in the modern transformational process in Indonesia (Dhofier, 1982). Pesantren has the ethos of community reform and development (Ziemek, 1986; Rahardjo, 1988), and the attempt to solve the environmental issues (Ghazali, 1999). Through such role and function, pesantren has transformed its purpose, from education and social institution to social and economic empowerment function.

Pesantren Arrisalah Ciamis develops the fishery economics sector; pesantren Darussalam Gontor also grows its agriculture and plantation while pesantren Al-Amin Sumenep develops the maritime-based economic industry. Pesantren Ta'miriyah Surakarta develops several businesses (Zailani, 2008). Pesantren Azzainiyyah Sukabumi of West Java promotes community economic empowerment to alleviate poverty by establishing Community Financial Institution of Welfare Mosque Council. Pesantren Sidogiri Pasuruan empowers the economics community (umat) through pesantren's cooperatives, Baitul Mal Wattamwil, Sharia-based Rural Bank, garment, and other business sectors, and have 16 trillion IDR asset. The economic progress and the development of pesantren activate the economic community development in some regencies in East Java and other provinces. In the celebration of the cooperative day on July 12, 2018, led by Indonesian President Joko Widodo, Koperasi Sidogiri (Sidogiri Cooperatives) becomes one of the best national cooperatives.

Pesantren Al-Ittifaq Rancabali Bandung has successfully conducted the economics community development in agribusiness as a sustainable process (Fauroni, 2014). The process builds on three bases. Firstly, thriving economic empowerment is determined by the establishment of an economic culture that has its consciousness, experience, network, leadership, role modeling, and local wisdom. Secondly, the competitive advantage in dealing with the global economy is the consequence of keen economic consciousness among corporate businesses. Thirdly, the achievement of prosperous umat (community) is the determinant of success.

Pesantren Al-Amin conducts the development of pesantren's gradually and sustainably mission in social-economical and educational sectors in some stages. This development stage can be mapped as follows. The first is the social-economic inclusive stage. This stage is the phase of an opening developing environment involving many parties in the social-economic development process. The scene begins since Haji Zarkasyi's coming back from his journey in Jakarta to work and learn embroidery skills in a Chinese employer for 8-9 years (1952-1960s). His experience in Jakarta inspires him to build a business in Tanjung Kawalu Tasikmalaya. 
Haji Zarkasyi invites the surrounding people to participate in his business by teaching embroidery skills and employing them. He also gives moral values through skills and abilities. They can master embroidery skills within five months. Then, some employees separate themselves and establish their own embroidery business independently. In this socialeconomics inclusive stage, Haji Zarkasyi gives them the embroidery machine. In the first stage, he focused on the pioneering and developing embroidery business community (1961-1977) until Tjiwulan Embroidery Education Institution established in 1978.

The second is moral and economic integration. In this stage, there are two categories of ethical integration approach (through education and religion) to solve the economic problems that occurred at that time. Firstly, the religious solution to economics business behavior (fraud) problem answers as a short-term solution. Secondly, education in religion and science, as well as business skills solutions are long term solution and becomes the next mission of Haji Zarkasyi's family. Through al-Amin Islamic Education Foundation, Haji Zarkasyi's family manages pesantren, embroidery business, and hajj. In this stage, economics, religion, and education dynamically integrate as parts of devotion to Allah.

The third stage is moral-economic integration and pesantren economic business stabilization, which consists of the Islamic education foundation (1985), Tjiwulan cooperatives (1987), Tanah Abang market expansion (1989), and premiere export to Middle East (1991). Then, the establishment of recitation event, Hajj and Umrah Guidance, pesantren's prospect (1998), the establishment of YPI Al-Amin, and the establishment of PT. Tjiwulan Mandiri Putra (2000), the establishment of Islamic senior high school in 2001, the establishment of integrated Junior High School in 2009 and PT. Tjiwulan Mandiri Putra Probolinggo in 2010.

The fourth is CED and charity for the community solution stage. This stage is a form of real innovation action that aimed not only to solve the social problem but also to educate. The example of charity activity is house renovation, helping poor people, scholarship, and charity for a natural disaster. Those fourth stages are the expansion of pesantren's effort to reach its aim in creating a robust network system, good business, Muslim employer community, and leading supporter of education institution operation.

\section{Pesantren Agility: Source, Competitiveness, and Productivity}

A structural-functionalism study attempts to build a social system or structure through analyzing the functional relationship pattern among individuals, groups, or social institutions within a community in a certain period. The technical analysis attempts to answer a question of social items' reason that has a consequence on the overall operation of the social system (Marzali, 1997). In this context, pesantren is a social institution that actively contributes to the social system in its diverse functions. An active pesantren's role in such different services has led to the expansion or the transformation of pesantren's function. 
The source of agility competency from several pesantren becomes more exciting to be studied. The expansion of pesantren's function into the economic sector is inseparable from the value system owned by pesantren. Pesantren has diverse values that developed from the Islamic tenet source in its various aspects. They are values and principles of imperative to hard work, mutual help, and cooperation. It is better to give than to receive, paying zakat, free from poverty, hajj performance, etc. Those principles and values affect the action to be powerful economically (Masruri \& Fauroni, 2013).

The above facts, especially in pesantren Al-Amin Kawalu Tasikmalaya, indicate the pesantren's ability to assume many responsibilities and social-economic role in adapting to the community's change in local, national, and global. Pesantren serves multifunction, including religious, education, and economic development in various aspects.

Therefore, social-cultural is a basis of encouragement to expand the primary function, especially the agility in economic development. Then, agility is also able to improve economic productivity. Consequently, it will have independent education, social-economic, and community economic development (CED) or empowerment.

Similarly, Islam teaches people to be honest in their behavior, including in business relations and cooperation. It is imperative to prioritize the quality of production and be wise to the consumers. Meanwhile, if the business operates resentfully and jealously, through unfair competition and tackling each other, the business ought to be destroyed (KH. Abdul Muhsin, personal communication, 2018).

It truthfully implies in QS An-Nisa, 4: 29. It is the consciousness of Islamic principles that encourages the establishment of pesantren Al-Amin. After many alumni of embroidery education institutions become employers and suppliers of embroidery garments to Tanah Abang market, unfair competition occurred by lowering the price and paying less attention to its quality and sustainability business in the future. Through pesantren, moral-economic values can be integrated into the implementation of moral economic activity.

Therefore, the contribution of pesantren is inseparable from Islamic principles and behavior in entirely steps and movements. The function of pesantren is as the goalkeeper of morality in the social life of community and nation. It serves as the implementation of the main mission tafaqquh fiddin, which expanded into community economic development and empowerment. Islam religion, as mentioned in QS A1-Qasas, 28: 77, addresses not only sacred but also the separated impure one.

However, pesantren is very rich in the valuable sources of Islamic religion's principle that underlined by its movement and roles. As a social growing and developing institution along with the community, pesantren potentially expands its purpose and function from socialeducation proselytizing to economic empowerment. 
Wahid (1999) states the other elements of pesantren, namely a unique value system. This unique system has importantly contributed to creating a social charity for the community advance's purpose. In the context of its overall functions and roles, Wahid puts pesantren to be a subculture composed of three main elements: (1) independent leadership pattern (uneasily coopted by the state); (2) Kitab Kuning (salaf book) or classical reference in last centuries; and (3) Using (Islamic) value systems in the society.

Therefore, in the context of social role in community empowerment, pesantren has developed civil society. According to Wirosardjono (1988), pesantren strongly emphasizes moral independence, simplicity, and hard work values. Sovereignty emphasizes santri and surrounding people to create a friendly and pleasant environment in the community.

Pesantren is inseparable from the community's role. Pesantren grows and develops from and for the community. The main objective of pesantren, among others, is to conduct social transformation toward an independent and prosperous social order. Pesantren is aimed to dedicate itself to the development of Islam proselytizing. It develops a good community's values. The independence and wealthy mean to cover all aspects, not only material but also immaterial equally. Welfare includes the fulfillment of material, spiritual, individual, and social needs. Material adequacy in the world is intended to achieve the sufficiency in the hereafter, constituting an eternal life (Misanan, 2009).

Pesantren's focus on agility can be seen from the value systems and the direction of the leadership's style. That is one of the factors which have determined the direction of pesantren's economic development and economic empowerment for its community environment. Pesantren Al-Ittifaq is influenced and lead by Kiai Fuad Affandi's leadership spirit. He has a strong history in entrepreneurship to develop economic potency in his pesantren and its neighborhood. Then, pesantren Arrisalah Ciamis is affected by the surrounding natural environment, such as clean water, thereby it develops fishery business as their concern. The transformation of pesantren's function happens when pesantren well understood modernization as a challenge and opportunity. Pesantren occupies the position as Indonesia's Islamic basis in learning Islamic sciences and implements it in society, nation, different communities, and even in international relations. Consciously, pesantren is right to use intensification patterns in the aspect of life (Fawait, 2013).

A good understanding of external challenges can be called pesantren agility. Pesantren agility is defined as flexibility in dealing with external problems applied by pesantren in a synchronous up and bottom strategy. In developing its agility, particularly in economics, pesantren passes four stages: cultivation culture, quality commitment for economic competitiveness, leadership and target-strategy and market orientation, and customers' commitment to developing the economic function of pesantren. Those four stages are presented in the figure below. 


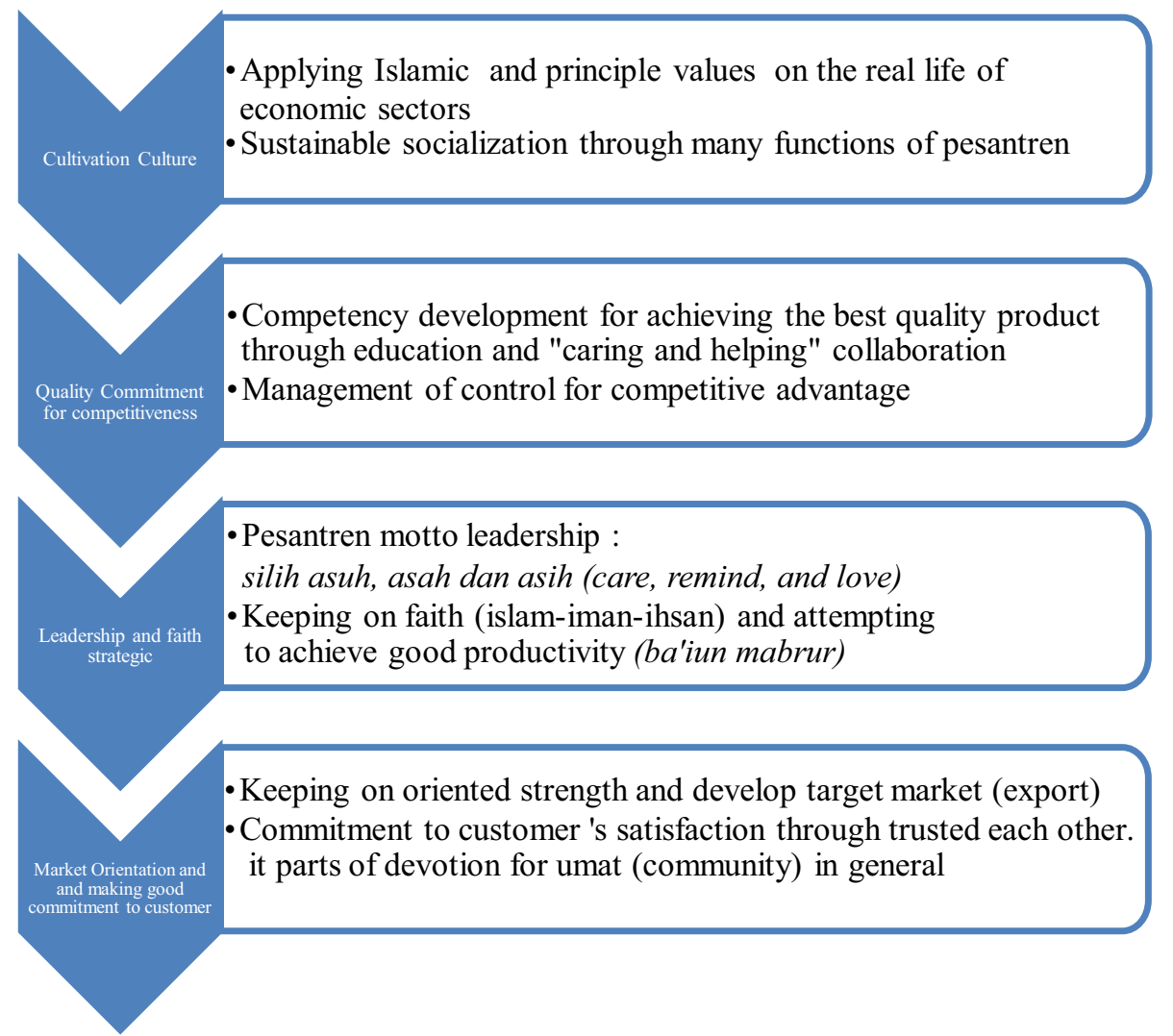

Figure 1. Pesantren Agility: Implementation and Outcome

From the above figure, it can be seen that pesantren agility, particularly in the economic sector, can be achieved through a sustainable process that originated from intellectuality. The cultivation culture stage builds Islamic power, which can be pesantren's culture. Then, the quality commitment stage, the energy of ghirah is strengthened by the development of committed competency to achieve the best quality product through "caring and helping." It is a collaboration among pesantren leaders and pesantren organization and pesantren economic community. This stage emphasizes on quality and control's culture for higher good products.

Moreover, the fight, leadership, and strategy stage show the decisiveness of pesantren's leadership because it maintains the stability of the quality process. Asuh, asah, and asih (care, remind, and love) leadership pattern is very effective, the collective consciousness of keeping obedient (Islam-Iman-Ihsan) and attempting to achieve better productivity (ba'iunmabrur). 
The last stage is the culture. Its priorities the strength and development target market, either the local market or particularly export market. Then, mutual commitment in pesantren organization and community is to keep maintaining the customer's satisfaction through trusted each other and to share such as a network. Its parts of the implementation of devotion to Allah and the development of the community economy. The economic community development is an integral part of mahdhoh and ghoirmahdhoh worships and devotions.

\section{CONCLUSION}

From the above-elaborated result, it can be found the fact that pesantren agility as the epicenter of social-education function's strength and mainly the purpose of community economic development through the transformation of pesantren institution. The pesantren institutional change is the expansion of pesantren function and mission in dealing with economic globalization, which involves all aspects of the community's life. This research proves that agility originates from the intellectual capital of pesantren tradition, which is the implementation of fundamental Islam religion principle that concerns social and economic.

Moreover, pesantren's agility has been applied to the development of community economic development. It starts with the nearby community, corresponding to its community's economic need. Pesantren Al-Amin has functioned its institution and complete resource as the agent of community economic development in many aspects of life, such as economic empowerment and poverty eradication as the process of community economic's stability. Pesantren's agility in the economic sector is implemented through four stages: cultivation culture, quality faith-commitment and leadership, and market orientation, and commitment to customers.

\section{REFERENCES}

Adi, I. N. R., Astawa, I. N. D., Taun, I. N., \& Widjaja, I. K. M. (2016). Community Economic Development of the Coastal Area in Gianyar Regency of Bali Province, Indonesia. Journal of Economics and Sustainable Development, 7(24), 118-122.

Armstrong, H. W., Kehrer, B., Wells, P., \& Wood, A. M. (2002). The Evaluation of Community Economic Development Initiatives. Urban Studies, 39(3), 458-481. https://doi.org/10.1080/00420980220112784.

Bogdan, R. C. \& Biklen, S. K. (1992). Qualitative Research for Education: An Introduction to Theory and Methods. USA: Pearson.

Chrisen. (2007). Agile Manufacturing, Strategi Perusahaan Menghadapi Dinamika Lingkungan. Equiblirium: Jurnal Bisnis \& Akuntansi, 1(2), 66-81. 
Creswell, J. W. (1998). Qualitative Inquiry and Research Desain. California: Sage Publications. Dhofier, Z. (1982). Tradisi Pesantren: Studi Pandangan Hidup Kiai. Jakarta: LP3ES.

Fauroni, R. L. (2014). Model Bisnis ala Pesantren, Filsafat Ukhuwah Menembus Hypermarket Memberdayakan Ekonomi Umat. Yogyakarta: Kaukaba-Bisyar Consulting.

Fawait, A. (2013). Transformasi Pengembangan Tradisi Pondok Pesantren. Edu-Islamica: The Indonesian Journal of Education and Islamic Sciences, 5(1), 1-30.

Felipe, C. M., Roldan, J. L. \& Leal-Rodríguez, A. L. (2017). Impact of Organizational Culture Values on Organizational Agility, Sustainability, 9(12), 23-54. DOI: $10.3390 /$ su9122354.

Ganguly, A., Nilchiani, R., \& Farr, J. V. (2009). Evaluating Agility in Corporate Enterprises. International Journal of Production Economics, 118(2), 410-423. https://doi.org/10.1016/j.ijpe.2008.12.009.

Ghazali, M. B. (1999). Pengembangan Lingkungan Hidup dalam Masyarakat, Kasus Pesantren An-Nuqayah dalam Menumbuhkan Kesadaran Lingkungan Hidup. Disertasi: IAIN Sunan Kalijaga Yogyakarta.

Hajevar, S. Y., \& Kharazian, M. A. (2016). Analyzing Effect of Organizational Agility and Intellectual Capital on Productivity of Human Resources Through Spiritual Leadership (Case Study: Social Security Organization of Chaharmahal and Bakhtiari).

International Business Management, 10(10), 1893-1900. DOI:

10.36478/ibm.2016.1893.1900.

Horikoshi, H. (1987). Kyai dan Perubahan Sosial. Jakarta: P3M.

Marzali, A. (1997). Struktural Fungsionalisme. Antropologi Indonesia, 52, 33-43. https://doi/org/10.7454/ai.v0i52.3314.

Masruri, S., \& Fauroni, R. L. (2013). Peran Modal Sosial Filsafat Tri Tangtu Silih dalam Pemberdayaan Ekonomi Masyarakat di Desa Alamendah Rancabali Bandung. Inferensi: Jurnal Penelitian Sosial Keagamaan, 7(2), 275-296. https://doi.org/10.18326/infs13.v7i2.275-296.

Misanan, M. (2009). Ekonomi Islam. Jakarta: Rajawali Press.

Pabbajah, M. (2017). Praktik Ekonomi Islam pada Komunitas Keagamaan di Sulawesi Selatan. Al-Ulum,17(1), 143-165. DOI: https://doi.org/10.30603/au.v17i1.107.

Perera, S., Soosay, C., \& Sandhu, S (2014). Does Agility Foster Sustainability: Development of A Framework From A Supply Chain Perspective. Australian and New Zealand Academy of Management, 1-19.

Rahardjo, M. D. (1988). Pesantren dan Pembaharuan. Jakarta: LP3ES. 
Saha, N., Gregar, A., \& Saha, P. (2017). Organizational Agility and KM Strategy: Are they Effective Tools for Achieving Sustainable Organizational Excellence?. New Trends and Issues Proceedings on Humanities and Social Sciences. 4(10), 110-117. https://doi.org/10.18844/prosoc.v4i10.3084.

Setyawan, D. (2017). Gerakan Intelektual Kolektif Komunitas \#Ayokedamraman dalam Pemberdayaan Warga Membangun Pariwisata Alam dan Ekonomi Kreatif. Nizham: Jurnal Studi Keislaman, 5(2), 15-28.

Singh, J., Sharma, G., Hill, J., \& Schnackenberg, A. (2013). Organizational Agility: What it is, What it is not, and Why it matters". Academy of Management Proceedings, 1-40. https://doi.org/10.5465/ambpp.2013.11813abstract.

Steenbrink, K. A. (1986). Pesantren, Madrasah, Sekolah: Pendidikan Islam dalam Kurun Modern. Jakarta: LP3ES.

Su, G. (2011). Exploring Requirements of Agility for Knowledge Management. Proceedings $6^{\text {th }}$ Conference on Professional Knowledge Management, 371-381.

Suyata. (1985). "Pesantren sebagai Lembaga Sosial yang Hidup", dalam M Dawam Rahardjo, ed., Pergulatan Dunia Pesantren Membangun dari Bawah, Jakarta: P3M.

Wahid, A. (1999). "Pondok Pesantren Masa Depan", dalam Marzuki Wahid dkk. (peny). Pesantren Masa Depan, Wacana Pemberdayaan dan Transformasi Pesantren. Jakarta: Pustaka Hidayah.

Wibowo, E. Y. (2017). Islam dan Kewirausahaan: Dinamika Sosial Ekonomi Komunitas Pengrajin Batik di Karangkajen Yogyakarta (1950-1975). Jurnal Sejarah Peradaban Islam, 1(1), 113-138, DOI: http://dx.doi.org/10.30829/j.v1i1.1003.

Wirosardjono, S. (1988). The Impact of Pesantren in Education and Community Development in Indonesia. Jakarta: P3M.

Yin, R. K. (1984). Case Study Research: Design and Methods. Newbury Park, CA: Sage Publisher.

Zailani, A. (2008) "Basis Ekonomi Pesantren: Model Pembiayaan Pesantren Ta'mirul Islam Surakarta Jawa Tengah", in Irwan Abdullah dkk. Agama, Pendidikan Islam dan Tanggung Jawab Sosial Pesantren. Yogyakarta: Sekolah Pascasarjana UGM kerjasama Pustaka Pelajar.

Ziemek, M. (1986). Pesantren dalam Perubahan Sosial. Jakarta: P3M.

Interview:

KH. Wawan Nawawi.

KH. Abdul Muhsin. 